\title{
CONSTITUTIONS AND THEIR APPLICATION IN THE NETHERLANDS DURING THE MIDDLE AGES $\left(^{*}\right)$
}

In a recent article Professor B. Lyon has written a masterly comparative study of medieval constitutions in Europe with a view to determining the circumstances and optimum conditions which led to their origin (1). He infers that only in England and in the duchy of Brabant did they exist - although in the Netherlands the Prinsbishopric of Liège should be added, which Lyon spoke of in a former contribution ( ${ }^{2}$ ) and also Poland, Bavaria, Switzerland, and eventually Aragon, Brandenburg and Wurtemberg might have been considered $\left({ }^{3}\right)$ - and he then proceeds to analyze the essential differences between these and other countries. In England and Brabant a powerful monarch reigned in a centralized and homogeneous state where the economic and political evolution developed gradually and without violence. However, the weight of the strong central power was kept in equilibrium by the coalition of an active nobility and a young municipal "bourgeoisie" so that a balance of power was obtained.

These conditions did not exist in Germany nor in Italy where the powerful cities were confronted by a feeble authority, nor in France,

(*) R. VAN UYTVEN is the author of the part concerning Brabant, W. Blockmans of that concerning Flanders. The latter part has been revised by Prof. A. Verhulst and Prof. W. Prevenier. We thank them sincerely for their important remarks.

(1) B. Lyon, Medieval Constitutionalism : a balance of power, in Album H. M. Cam, Etudes Comm. internat. Histoire des Assemblées d'Etats, XXIV, Leuven-Paris, 1961, p. 157-183. In fact, Liège does not confirm the author's thesis.

(2) B. Lyon, Fact and fiction in English and Belgian constitutional law, in Medievalia et Humanistica, X, 1956, p. 82-101, p. 88-90.

(3) A comparative publication of constitutional laws : W. NAEr, Herrschaftsverträge des Spätmittelalters, Bern, 1951. 
where to the contrary strong monarchs encountered only slight opposition from a divided nobility and weak cities, neither was it the case in Flanders. Should such a balance of power have existed there perhaps in the 12 th century $\left({ }^{1}\right)$, it was certainly broken in the 13 th century in favour of the cities whose unequalled economical expansion quite overshadowed the powerless countesses and decaying nobility.

At the time the first constitutions were set up in England and Brabant, the evolution in Flanders had already gone further and the opportunity passed by. Scholars' attention has often been drawn to this different evolution in the neighbouring territories of Flanders and Brabant. The absence of such constitutions in Flanders has even been considered as a deviation from the general tendency according to which institutions there were set up some decades earlier than in Brabant. The faster evolution in Flanders, however, rendered the institutions which were set up elsewhere superfluous. When the optimum moment is missed, the establishment of legal phenomena of any kind may be prevented for a long time, or even totally $\left({ }^{2}\right)$. The duality though has deeper roots. The absence of any constitution, however, has in no way prevented the Flemish cities, or later on the Members, or the Estates, to exercise de facto all authority granted by the English, Brabant and Liège documents, even earlier than the Brabant or Liège Estates. Coinage may be cited here as a very striking example. In the 13th century the Scabini Flandrie not only exercised an effective control over the issue of such, but they also played a real part in the preliminary negociations concerning the monetary worth of the coins $\left(^{3}\right)$. It was only in 1344, and the further 14th century,

(1) Projected assembly of barons, clergy and commoners in 1128. (GALBERT, Histoire du meurtre de Charles le Bon, ed. H. Pirenne, Paris, 1891, ch. 95, p. 139) : see J. Dhondr, Les origines des Etats de Flandre, in Anciens pays et assemblées d' fitats, I, 1950, p. 18-19 and F. L. Ganshor, Les origines du concept de souveraineté nationale en Flandre, in Revue d'Histoire de Droit, XVIII, 1950, p. 135-158; p. 147-149.

(2) See in comparison: R. C. VAN CAENEGEM, L'histoire du droit el la chronologie. Réflexions sur la formation du « Common law» et la procédure romano-canonique, in Fítudes G. Le Bras, Paris, 1965, p. 1459-1465.

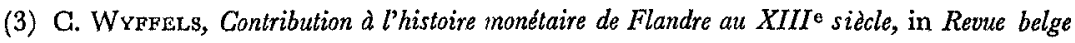
de Philologie et d'Histoire, XLV, 1967, p. 1117-1120 and mainly 1131-1135. See also J. Dhondt, Les origines, p. 22 et sq. 
in application of the Walloon Gharter (1314), that the cities of Brabant were admitted to participate in the coinage policy and control. The question therefore remains what was the import of the constitutions in those countries where they existed, and on the other hand the lack of them in Flanders where, notwithstanding, the Estates disposed of an effective influence. In connexion with this the point is raised as which changes finally led to the establishment of a first constitution in Flanders in 1477.

\section{$*^{*} *$}

The Magna Carta of 1215 in England was followed by a series of constitutional documents $(1258,1297,1300,1311)$ which in each case brought but few changes, but rather pointed to the necessity of clearly bringing before the eyes of the king the rights of his subjects, whenever his position had become temporarily weak (often financially) ${ }^{(1}$ ). The institution of a control commission (foreseen in the Magna Carta) of 25 barons who were to examine the validity of the acts of the king and his officials could hardly be effective inasmuch as in case of a refusal by the king the only resource left was force. The situation leading to a revolution or a general mobilisation of the minds and a congruence of all subjects' interests occurs very scarcely however, which enfavoured the king. In practice therefore the resistance of the subjects was limited to financial matters (the permission of taxes), hence these regular confirmations of their rights without the possibility of effective resistance afterwards. The Magna Carta was indeed formally revoked so that its import was principally limited to a vague general formula of a certain number of socalled inalienable rights of the subjects. These rights became more and more idealized as their date of issue grew more distant.

Control organizations of this kind have existed elsewhere, but their success was just as slight : in Luxemburg the Council of 10 in 1214, in France the Council of 28 in 1356. A similar situation existed also in Brabant.

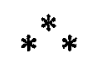

(1) Lyos, Fact and fiction, p. 82-84. 
Up to the 12th century the political importance of the towns in the duchy of Brabant has been negligible. Their commerce and industry, stimulated by the growing traffic from the flourishing industrial centers of Flanders to the Rhine-region, experienced a real upraise at that time (1). Before, a collusion between the towns, such as it manifested itself in Flanders through the scabini Flandrie or already after the murder of Charles the Good (1127), did not exist in Brabant, for the simple reason that the duchy itself still did not constitute a unified territory $\left({ }^{2}\right)$. Besides, by some kind of genetical miracle male and major dukes peacefully succeeded one another here without any disturbance until $1248\left({ }^{3}\right)$. So their position was constantly strengthening both at home and abroad. Consequently any interference of foreign authorities, such as the kings of France in Flanders or the dukes of Brabant themselves in Liège, was out of the question. Brabant being safe from foreign influences, the relation between the duke and his towns was one of a more harmonious collaboration. Moreover, the dukes' great ambition of giving a real content to their title of duke of Lotharingia was in keeping with their towns' commercial interest in the Meuse - and Rhine-regions.

Whilst the towns were constantly growing, the genetical fortune of the Brabant dynasty abruptly ended in 1248. From this year on to 1430 practically each succession to the throne of Brabant was a threat to the ducal authority by the absence of a major successor (1248, $1261,1312,1415)$ or of a male heir (1356) or of any direct heir at all $(1406,1430)$. In 1248 duke Henry II thought it wise to grant a general charter confirming to the country as a whole fiscal and judicial liberties some towns and communities had already been enjoying. By doing so he hoped to facilitate the succession of his young son and reinforce his subjects' loyalty towards a successor, the youthful Henry III. As far as we know, his act was a spontaneous one and it was certainly not the result of a pression by the towns, not even

(1) P. Bonenfant, L'origine des villes brabangonnes et la « route» de Bruges à Cologne, in Revue belge de Philologie et d'Histoire, XXXI, 1953, p. 446-447.

(2) F. L. Ganshor, Coup d'eil sur l'évolution territoriale comparée de la Flandre et du Brabant, in Annales de la Société royale d'Archéologie de Bruxelles, XXXVIII, 1934, p. 83-95.

(3) Exception made for the childhood of Godfrey III in 1142. 
mentioned in this first constitution of Brabant $\left.{ }^{(}\right)$. In the last days of his life, Henry III, repeated for the very same reason his father's action. The constitution he granted in 1261 was nothing but a renewed and somewhat augmented edition of the charter of 1248. Obviously Henry had not respected the promises his father and he himself had made in 1248. On the contrary, he had even got hold of the community grounds at the expense of the towns and villages. His "will" was a manifestation of repentance, but, as his father's, it only made promises without any security or sanction. However, at the end of his will Henry III incited his subjects to look after its realisation $\left({ }^{2}\right)$.

So they did ! A few months after his death the towns of Brabant joined hands in an urban league $\left(^{3}\right)$. The demographic and financial power of the towns, associated for protection against the rapacy of foreign regents and the horrors of a struggle for the throne, turned out to be unmatched in the duchy. Their assent and collaboration was now sought for every important political decision and even for financial arrangements concerning the very ducal demesnes. As mighty dukes as John I and his son John II had to pay their aids with new and more privileges and the nobility were eager to obtain the towns' guarantee under the duke's charters $\left(^{4}\right)$. In fact John I's vast international policy proved to be one of the main causes of the decline of the ducal authority in Brabant. The conqueror of Limburg ran out of cash and he and his successors got completely caught in the financial grip of their subjects. Leaving a son of twelve, John II, as Henry II and Henry III, wished to smoothen the path for this youngster by granting a constitution to the country during a great assembly at Kortenberg. This "charter of Kortenberg" (1312)

(1) G. Boland and E. Lousse, Le testament d'Henri II, duc de Brabant, in Revue du droit franfais et étranger, XVIII, 1939, p. 348-385.

(2) G. Boland, Le testament d'Henri III, in Revue d'Histoire Ecclésiastique, XXXVIII, 1942, p. $59-96$.

(3) G. Boland, Un siècle d'alliances interurbaines en Brabant, in Miscellanea A. De Meyer, vol. I, Louvain, 1946, p. 613-625 and Les deux versions du'pacte d'alliance des villes brabansonnes de 1261-1262, in Revue belge de Philologie et d'Histoire, XXIII, 1944, p. 289-294.

(4) R. VAN UyTVEN, Standenprivilegies en -beden in Brabant onder Jan I (1290-1293), in Revue belge de Philologie et d'Histoire, XLIV, 1966, p. 413-456. 
repeated the old fiscal and judicial privileges of the two Henrys, but it foresaw a council of control the regular assemblies of which enabled a more effective defense of the Brabant liberties than the occasional meetings of the towns and nobility. The death of John II, more sudden than expected, somehow delayed the installation of the Council of Kortenberg $\left(^{1}\right)$. Moreover the dissipation by and the rivalry between the foreign regents deeply displeased the towns, which in July 1313 reinforced their union $\left({ }^{2}\right)$. Once more the distress of the ducal finances gave them an excellent weapon. The Walloon Charter of 1314 temporarily yielded a complcte control and authority over the ducal finances and administration; the so-called Flemish Charter was a definite constitution in many domains completing and confirming the Charter of Kortenberg ( $\left.{ }^{3}\right)$.

The towns of Brabant now reached the height of their power, surpassing even those of Flanders, which in this very years were ultimately compelled to render an account about their finances to the count, backed up by the king in this respect $\left(^{4}\right)$. In Brabant the duke never succeeded in hearing the towns' accounts ( $\left.{ }^{5}\right)$, but on the contrary

(1) J. Van Der Straeten, Het charter en de raad van Kortenberg (Universiti,it te Leuven. Publicaties of het gebied der Geschiedenis en der Pirllologite, 2nd ser., vol. 46-47), Brussels, 1952, 2 vol.

(2) G. BoLAND, Un siècle d'alliances interurbaines..., p. 624.

(3) As a matter of fact both charters of 1314 were in « Walloon » or French on account of the presence of the duke's father-in-law, the French prince of Evreux. As E. Pouruct, Hisloire de la Foyeuse-Entrée de Brabant et de ses origines (Mémorres couronnés et DEs SAVANTs Étrangers de l'Académie royale de Belgrque. vol. XXXI), Brussels, 1863, p. 37, suggested, the charter containing the everlasting constitutional rules, got soon translated into Flemish for more commodity. When elsewhere in this paper the Walloon charter is mentioned, the so-called Flemish charter is meant. E. Lousse, Les deux chartes romanes brabanfonnes du 12 juillet 1314, in Bulletin de la Commission royale d'Histoire, XCVI, 1932, p. 1-47 published the original French texts of both documents.

(4) W. Prevenrer, Quelques aspects des comptes communaux en Flandre au moyen äge, in Finances et Comptabilité urbaines du XIII $I^{\mathrm{e}}$ au XVI ${ }^{\mathrm{C}}$ siècle (Pro Crvitate. Collection historre, in-8o, vol. 7), Brussels, 1964, p. 119-122.

(5) A glance at the list of towns' accounts kept in the archives of audit offices will sufficiently establish this contrast between Brabant and Flanders (A. Pinchart, Inventaire des archives des Chambres des Comptes, vol. V, Brussels, 1879, p. 50-60 and 65-125 and M. BRucuxt, Archives départementales du Nord. Répertoire numérique, Série B (Chambres des Comptes de Lille), vol. I, Lille, 1921, p. 195-198 and H. NeLIs, Chambre des Comptes de Flandre et de 
his own treasury was administered by his subjects. It should be stressed that the Brabant towns had the lead in all this and the nobility only followed. In the Council of Kortenberg for instance were sitting four knights but ten townsmen and in the financial commission of August 1314 the nobility were only two against the representatives of eight towns. Later on in the numerous analogous commissions the proportion was much the same $\left(^{1}\right)$. The history of the Council of Kortenberg $\left({ }^{2}\right)$ and the events of 1355 , preceding the recognition of Joan and Wenceslas as heirs apparent of Brabant $\left({ }^{3}\right)$, point to the nobility's lack of initiative and their docility towards the towns in these matters. This is most certainly connected to the intimate relations between the nobility and the patrician families the towns' magistrates were recruted from. Besides, many knights and noblemen had themselves registered in the towns as so-called "foreign citizens" in order to enjoy the urban privileges and eventually to become a towns' official ( $\left.{ }^{4}\right)$. The Charter of Kortenberg (1312) and the Walloon Charter (1314) remained the basic constitutions of Brabant throughout the 14th century. Being normative texts, the historian ought to wonder about their application. For sure, the Gouncil of Kortenberg's sessions are mentioned in $1324\left(^{5}\right)$, but it can not be a mere coincidence that in 1332, the year when duke John had an international coalition of surrounding princes to face, both charters were solemnly corroboratcd and a general inquiry on the behaviour of the ducal officers was ordered and executed. In the following years the many-sided authoritarian activities of the Council of Kortenberg

Brabant. Inventaire des Comptes en Rouleaux, Brussels, 1914, p. 121-124. See also 1i. BLockMANs, Le conlrôle par le Prince des comptes urbains en Flandre et en Brabant au moyen âge, in Finances et Comptabilité urbaines..., p. 287-338.

(1) J. Van Der Straeten, op. cit., vol. I, p. 123-127, 150-151, 199, 246 n. 116.

(2) J. Van Der Straeten, op. cit., passim and P. Gorissen, Het Parlement en de Raad van Kortenberg, in Anciens Prys et Assemblées d'Lt'tats, XI, 1956, passim.

(3) R. VAN BRAGT, De Blijde Inkomst van de hertogen van Brabant Johanna en Wenceslas (3 januari 1356). Een inleidende studie en tekstuitgave, in Anciens Pays et Assemblées d'Etats, XIII, 1956, p. 21-16 and E. Lousse, La Joyeuse Entrée de Brabant, in Schweizer Beiträge zur Allgemeinen Geschichte, X, 1952, p. 148-149.

(4) P. Gorissen, op. cit., p. 38-39. See also P. Goddino, La bourgeoisie foraine de Bruxelles du XIV a $V^{\mathrm{e}} X V I^{\mathrm{e}}$ siecle, in Cahiers Bruxellois, VII, 1962, p. 1-64.

(5) J. Van Der Straeten, op. cit., vol. I, p. 141-142. 
are beyond all doubt $\left({ }^{1}\right)$. In 1344 , as an article of the Walloon Gharter prescribed, the urban magistrates were invited to assist to a coinage test $\left({ }^{2}\right)$. Somewhere in 1344 or 1345 , John III having reaffirmed his international position, the Council of Kortenberg suddenly fainted away until July 1350, when its activities took up again and a new general inquiry or enquête started $\left({ }^{3}\right)$. This does not imply that the influence of the towns in the duchy has been done away with during those ycars. In fact in 1348 they negociated with the duke about an aid thcy were legally held to on account of the marriage of the duke's children, and even got themselves new privileges granted in recurn $\left.{ }^{4}\right)$. All those years they have been directly associated with the duke's international policy. The king of France himself thought it useful to ask their guarantee for the treaty he had signed with the duke in $1347(5)$.

The towris are even more revealing themselves the masters of the duchy in 1355. A new union made their determination clear to keep the country one and undivided and protected against violations of their rights by a foreign consort of the heiress of Brabant. Hence they claimed the new dukes Joan and Wenceslas should enforce in one great constitution all previous privileges and promise to safeguard the integrity of Brabant.

The content and the significance of the Inauguration Charter (Foyeuse Entrée or Blijde Inkomst) of 1356 and of each of its articles have been again and again and thoroughly analysed and commented $\left({ }^{6}\right)$. However the importance of "the most illustrious charter of

(1) J. VAN Der Straeten, op. cit., vol. I, p. 79-85 and 146-155.

(2) F. VERACHTER, Inventaire des anciens chartes et privilèges et autres documents conservés aux archives de la ville d'Anvers 1193-1856, Antwerp, 1860, p. 43, nr. 127.

(3) J. Van Der Straeten, op. cit., vol. I, p. 79-85, 146-184.

(4) For instance the privilege of Louvain of 27 June 1348 (J. Botndale, Brabantsche Yeesten, ed. J. F. WILLEMs, vol. I, Codex Diplomaticus, p. 837-839). See also J. VAN DrR Straeten, op. cit., vol. I, p. 39-40.

(5) The treaty between Brabant and the towns of Liège (21 September 1347) for instance was drawn up "through the advise and the regulations of the good towns of Brabant" (J. Boendale, op. cit., vol. II, p. 468-469) ; H. Laurent, Les Conventions de Saint-Quentin (juin 1347), in Bulletin de la Commission royale d'Histoire, XCI, 1927, p. 141-146.

(6) Among all studies concerning the famous Brabant constitution of 1356 we will re- 
our national history" has been highly overstated. Already in 1956 Prof. B. Lyon warned against the fiction and the myth with which later centuries and especially that romantic and liberal 19th century have charged the Magna Carta of England and the Inauguration Charter of Brabant ( $\left.{ }^{1}\right)$. It is surprising that all Belgian scholars and even the perspicacious stranger Prof. Lyon failed to see that the so celebrated Inauguration Charter of 3 January 1356 has been very soon officially revoked, exactly as its even more famous English counter-part. As soon as August 1356 the Brabant constitution was a dead letter on account of the military occupation of the duchy by count Louis of Flanders. At the talks of Maastricht (February 1357) between the emperor Charles IV, 'the dukes Joan and Wenceslas and the Brabant towns, the validity of the Inauguration Charter was officially cried down. A revival of nationalism directed against the Flemish invader and the need of the emperor's support contributed to the acceptance of Charles' conditions and his claims about Joan's succession by Wenceslas and eventually by himself; as this was a flagrant contradiction to article 7 of the Inauguration Charter stipulating that a childless Joan was to be succeeded by her natural heirs (her sisters), the meeting at Maastricht was bound to result in the revocation of the constitution of 1356. All other charters and constitutions of the preceding dukes, of which the Inauguration Charter of 1356 was somehow the summing up, were of course validated $\left({ }^{2}\right)$.

call those already cited above of E. Lousse, R. VAN BRAGT and the much older but still valuable work of E. Poullet.

(1) Lyon, Fact and Fiction. In this context also P. A. M. GeurTs, Het beroep op de Blijde Inkomste in de Pamfletten uit de Tachtigjarige Oorlog, in Anciens Pays et Assemblées d' États, XVI, 1958, p. 1-15.

(2) R. VAN UXTVEN, De rechtsgeldigheid van de Brabantse Blijde Inkomst van 3 jamuari 1356, in Tijdschrift voor Geschiedenis, LXXXII, 1969, p. 39-48. Besides all circumstantial evidence about the revocation of the Inauguration Charter there are two essential texts to be reckoned with. On 21 February 1357 the town of Brussels acknowledged the restored dukes Joan and Wenceslas, universis et singulis liberatibus, immunimentis, privilegiis, litteris, juribus, consuetudinibus, usibus et indultis, nobis et oppido Bruxellensi, totique patriae Brabantiae communiter vel divisim, a recolendae memoriae divis romanis imperatoribus et regibus, necnon a felicis recordationis domino Johanne, quondam Brabantiae duce et suis antecessoribus olim ducibus Brabantiae, rite datis, approbatis in omnibus semper salvis (J. BoENDALE, op.cit., vol. II, p. 525). The reascending to the throne 
After his restoration, however, Wenceslas forgot even about those cngagements and the repentant towns were so eager to make him forget their unloyal attitude during the Flemish war ( $\left.{ }^{1}\right)$, that they did not wish to displease him. So the sessions of the Council of Kortenberg stopped again in spring 1357. As Louvain desperately tried to stir up the urban league $\left({ }^{2}\right)$, Peter Couthereel, a ducal officer in the old Brabant capital, was ordered to provoke a revolt and to overthrow the actual magistrate. For years the social unrest and the civil war at Louvain, protracted by the constantly changing sides of Wenccslas, were to inspire the towns' leaders to more docility towards the duke and to immobilize greatly the towns' actions $\left({ }^{3}\right)$. The general inquiry Wenceslas nevertheless yielded in 1363 has never been finished. The towns deprived of its supervision, in later times fully disregarded it $\left({ }^{4}\right)$.

The defeat and capture of Wenceslas and the Brabant nobility at Bäsweiler (22 August 1371) completely reversed the situation. In exchange for their contribution to the duke's ransom, the towns, having renewcd their union (18 February 1372) compelled the application of the charters of 1312 and 1314 as well as the organisation of a new general inquiry. In spite of Wenceslas' angry reactions they successfully vindicated their rights and even got control of and administered themselves the aid they had granted. Minting policy and

did not involve the validation of the privileges, including the Inauguration Charter of 1356 , the ducal couple had granted in their previous reign ; on the contrary the long enumeration of former charters they confirmed was ostentatiously restricted to those of John III and his predecessors. Besides in a charter for Tienen of 17 December 1358 it goes : "Moreover we arc confirming to our good men of our aforecited town all their letters, charters, privileges and laws they got sealed and granted from our predecessors dukes of Brabant, excepted only the letters, charters and privileges we granted our towns and country of Brabant at our first entrance and inauguration by our towns and country aforecited" (J. BoeNDALE, op. cit., vol. II, p. 738).

(1) H. LAUURent and F. QUICKE, La guerre de la succession du Brabant (1356-1357), in Revue $d u$ Nord, XIII, 1927, p. 91-104; R. VAN UYTVEN, art. cit., p. 44-45.

(2) J. VAN Der Straeten, op. cit., vol. I, p. 185-189.

(3) R. Van Uytven, Peter Couthereel en de troebelen te Leuven van 1350 tot 1363, in Mededelingen Geschied- en Oudheidkundige Kring voor Leuven en omgeving, III, 1963, p. 63-97.

(4) J. Bolsee, La grande enquête de 1380 en Brabant (Commrssion royal.e D'Hrstorre, in-80), Brussels, 1929, p. Xxi-Xxir and J. VAN Der STRAETEN, op. cit., vol. 1, p. 161-162. 
its supervision once more featured among their daily competencies ${ }^{(1)}$. Their power and influence were unrivalled throughout the duchy to such a point that they thought the Council of Kortenberg superfluous. So in 1383 it disappeared for ever, while each of the great towns preferred controlling and protecting its own district ( ${ }^{2}$ ). Although the Charter of Kortenberg was no longer looked after with regard to its most vital article, the towns' authority even in affairs of war, diplomacy and minting was greater than ever $\left({ }^{3}\right)$. Their decision exclusively made Anton of Burgundy duke of Brabant as successor to the childless Joan, disregarding on one side the protestations of the emperor and on the other side maintaining Brabant's independence towards Flanders-Burgundy $\left.{ }^{4}\right)$. Not unlike fifty years before, they seized the opportunity of recognizing this stranger to wrest from him a new constitution or Inauguration Gharter (1406), largely inspired to the letter as to the contents by the revoked Inauguration Charter of 1356. From now on, each new sovereign had to decree an analogous privilege. Those Inauguration Charters have been the basic constitution of the Brabant state. The one of 1356 however, although the first formulating the Brabant conceptions of liberty and state as a program for the generations to come, has only been valid for some months during the year $1356\left(^{5}\right)$.

The minority of Anton's successor, John IV, enabled the tradition of the Inauguration Charters to take root. Once more the towns gave proof of their determination to keep the duchy independent as well from the emperor as from the duke of Burgundy and to govern their minor duke themselves with a regency council. It is to be stressed

(1) J. Van Der Straeten, op. cit., vol. I, p. 189-255 and vol. II, p. 83-110.

(2) J. VAN Der Straeten, op. cit., vol. I, p. 259-263 and especially P. Gorissen, op. cit., p. 58-66 and 99-100.

(3) H. Laurent and F. Quicke, L'accession de la Maison de Bourgogne aux duchés de Brabant et de Limbourg (1383-1407). Première Partie : jusqu'à l'acquisition du duché de Limbourg et des terres d'Outre-Meuse (1383-1396) (MÉmoires in-8 ${ }^{\circ}$ de l'ACAdÉmie royale de Belgique, Classe des Lettres, vol. XLI, 1), Brussels, 1939, p. 150-159, 202, 207, 211-216, 292-303, 415, 433. Other examples in J. BoENDALE, op. cit., vol. II, p. 671, 678, 684-685.

(4) J. Strungers, Philippe le Hardi et les Ltats de Brabant, in Hommage au Prof. P. Bonenfant, Brussels, 1965, p. 383-408.

(5) R. Van UYTVen, De rechtsgeldigheid van de Brabantse Blijde Inkomst..., p. 47-48. 
where the towns are spoken of, that, since the last decades of the 14th century one should more correctly speak about the three "Estates" of Brabant, where the representatives of the clergy, the nobility and the towns met. In reality the towns were still the dominant partners in this association and notwithstanding the attempts of John IV and some of his noblemen they even got hold of government during several years ( $\left.{ }^{1}\right)$. In 1430 the long discussions between the Estates of Brabant and Philip the Good of Burgundy about the conditions of his succeeding his nephew Philip of St.-Pol ended in granting a new extensive Inauguration Charter $\left({ }^{2}\right)$. Nevertheless, the power of the great dukes of the West, Philip the Good and his son Charles the Bold, was so out of proportion to their Brabant predecessors, that the Estates were no longer able to encounter them as they did before. The Inauguration Charter the Estates extorted from the young duchess Mary threatened by Louis XI of France after the defcat and death of her father at Nancy (1477) was obviously a reaction against the centralisation measures, the financial extortions and judicial abuses her father and grandfather had committed in spite of their solemn charters and an attempt to prevent such things for the future $\left(^{3}\right)$. The transmission of practically all authority to the Estates which the young duchess had to tolerate for the danger she and her countries were in, had to end as soon as the greatest threats were over. Her son Philip the Fair explicitly stated in his Inauguration Charter (1494) that he did not rccognize the liberties and privileges the Estates had wrested from his mother $\left(^{4}\right)$. This survey of Brabant constitutional history during the middle ages is to prove at least one thing : the acquisition and the very possession of solemn constitutions did not by themselves secure the Brabant subjects the quiet enjoyment of them.

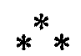

(1) E. Poullex, op. cit., p. 145-186; F. Favresse, L'avènement du régime dérnocratique à Bruxelles pendant le moyen age (1306-1423) (Mémoires in-8 ${ }^{\circ}$, Acadŕm rovale de Belgique, CLasse des Lettres, vol. XXX, 1), Brussels, 1932, p. 165-222.

(2) E. Poullet, op. cit., p. 187-254.

(3) E. Poullet, op. cit., p. 260-285.

(4) Den Luyster ende Glore van het hertogdom van Brabant, Brussels, 1699, Part III, p. 190. 
The evolution in the Prinsbishopric of Liège differed from that in Brabant only insofar as bloody conflicts were at the basis of texts which later could be interpreted as constitutions in view of their formulating of the rights of the subjects $\left({ }^{1}\right)$. In this respect the Peace of Fexhe (1316) was a truce as many others, rung from bishop Adolphe de la Marck by power of arms, but of which later on he took as little account as possible. 'The institution of a control commission in 1324 as well as in 1343, was ignored by this energetic bishop even though he had been obliged to give it official recognition. It was only in 1373 that this Council of XXII was instaured again and not earlier than in 1376 recognised by bishop Jean d'Arkel. A conflict between the Chapter and the city of Liège blocked all activities of the Council during eight months in 1386. It was inactive again from 1406 until 1420, from which date on, no members of corporations were allowed to have seats in it (2). The "balance of power" is hard to find in Liège; the sovereign's power changed quickly and new coalitions were constantly formed. Those constitutions which nevertheless were established were not seriously applied as long as the bishop retained sufficient power. Only force of arms on the part of the cities could force him to concessions, which however he renounced as soon as the military forces had retired behind the city walls. The constitutions were only of value when the cities themselves were able to enforce them.

The common elements in all these constitutions can be resumed essentially as :

- the confirmation of existing privileges (national, municipal and personal privileges) ;

- the recognition of the right of the subjects to denounce, with a view to punishment, such princely officials who transgressed these privileges ;

(1) F. Vercauteren, Het prinsbisdom Luik tot 1316, in Algemene Geschiedenis der Nederlanden, vol. II, Utrecht, 1950, p. 338-352 ; J. LEJEUNe, Het prinsbisdom Luik tot 1390, ibid., vol. III, Utrecht, 1951, p. 175-189.

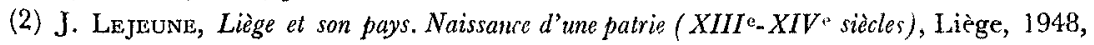
p. 397-401; and ID., La principauté de Liège, Liège, 194.8, p. 95. 
- the establishment of a control organization to investigate the claims against officials or against the sovereign, and to transmit such claims to the sovereign for correction.

In case the latter refuses to remedy the transgression, the subjects have the right to use force or disobedience against him.

It has, however, appeared that none of these constitutions was ever literally applied, and in most cases not in spirit either. The sketch of the evolution which led to the framing of a constitutional text is in fact only its previous history. It is certainly of as much importance to examine what its application has been, to which latter study but small attention had been given so far.

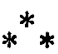

Let us now return to Flanders where the history of the Estates up to the beginning of the 15th century has been the object of sufficient study ( $\left.{ }^{1}\right)$ to be able to declare with certainty that the Flemish Estates intervened de facto in all matters which formed the object of constitutional laws in other countries. It would even seem to us that here the authority of the Estates was even larger and exercised earlier than elsewhere. Some princely decrees which for that matter have nothing in common with constitutional laws, confirm that, following ancient custom, the Members were consulted in all matters that concerned the entire country. The earlicst of these decrees dates back to $1305\left({ }^{2}\right)$; it is corroborated by the actual intervention of the cities in monetary matters during the 13 th century, as mentioned above $\left({ }^{3}\right)$.

(1) J. Dhondt, Origines, and W. Prevenuer, De leden en de Staten van Vlaanderen (13841405), (Verhandelingen Kon. Vlaamse Acad., Klasse d. Lejteren, 45) Brussels, 1961.

(2) Act dd. 8 May 1305 whereby Philip of Chieti and John of Namur granted the respect of urban customs and privileges : L. A. WARNKoEnig-A. E. GheLdolf, Histoire de la Flandre et de ses institutions civiles et politiques jusqu'd l'année 1305, vol. V, Paris, 1864, p. 445446. Further: 17 June 1436, ed. P. De ZaMan, Exposition des Trois Etats du pais et comté de Flandres, S.1., 1711, p. 94-96 : cf. DHondт, Origines, p. 26-28 and 47. The similar stipulations in these documents from different periods remove all doubts which the circumstances of their drafting might evoke.

(3) Supra, p. 400, n. 3. 
On the other hand the said text proves that the authority of the Estates was based upon no other prerogative than that of custom.

Such custom could on its part have been established only because in the balance of power, the cities constantly displayed such power that there was no domain in which the sovereign could pass them by (contrary to the brief conflict situations in other countries). This unwritten basis of the Flemish Estates was therefore more solid than the constitutional laws elsewhere because it was the reflexion of a permanent power-relation, constitutions on the contrary but one of short duration. Furthermore a specification of authority must inevitably be limitative. Did a vague declaration as that of 1305 not leave much more liberty for the effective authority of the Estates while at the same time not explicitly forcing the sovereign to concessions? From the point of view of the Flemish Estates, a written text could only have a restrictive effect. In their powerful position the Estates for that matter had no need of a formal ratification : indeed the law protects the weak. The fast economical development of the Flemish cities is therefore the primary cause of the apart situation of the country. This has still another result in respect of the absence of constitutions. In very early times already privileges were granted to the Flemish cities separately, particularly during the eleventh and twelfth century $\left({ }^{1}\right)$. On the one side this gave rise to a tradition not to issue privileges for the entire county unless in exceptional circumstances (2), and secondly the major motive for resistance against the sovereign was done away with. Whereas the granting of

(1) R. C. Van Cannegem, Coutumes et législation en Flandre aux XI el XII' siècles, in $L i$ bertés urbaines et rurales $d u X I^{\circ}$ au $X V^{\mathrm{e}}$ siècle, Pro Civitate, Col. Historre in-80, $\mathrm{n}^{0} 19$, Brussels, 1968, p. 245-279.

(2) Only 23 until the 17 h h century in the publication by G. Esprnas-C. VeruindenJ. Buntrinx, Privileges et chartes de franchises de la Flandre, Comm. roy. Anciennes Lois ET Ordonnances de Belgrous, vol. I, Brussels, 1959. At least two of these 23 charters had no general extent at all, but on the contrary affirm the particular character by their many promulgations : Privileges, no. 1 only concerns Ghent, in opposition to its version for Hainault where it was a real landcharter : W. Prevenrer, De Oorkonden van de Graven van Vlaanderen (1191-aanvang 1206). II. Uitgave, Kon. Comm. Geschredenrs in-4ㅇ, Brussels, 1964, nr. 214, mainly p. 443-444. The same remark concerns Priviliges no. $2:$ instead of one promulgation, at least scven promulgations for different cities are known: Prevenier,

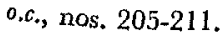


privileges in the 13th century was an urgent necessity in Brabant, this was no longer a problem in Flanders, thus obviating the granting of landcharters.

In the face of the exceptionally powerful situation of the cities, specially of the three largest, Ghent, Bruges, and Ypres, it may reasonably be asked. why the evolution did not progress here in the same way that led to the formation of the citystates in Italy. Indeed the economical (1) and demographic $\left(^{2}\right)$ status of the Three Members enabled them to make head against the entire county, including the count. Among the most important factors which prevented the different Members from transforming their territory into an autonomous state, there should be mentioned in the first place the wide juridical differences as from city to the rural districts, and even from city to city. The Members were hesitant to expand their privileges to the entire county. On their part the smaller towns and rural districts were not at all keen to sce their own freedom restricted by being brought entirely under the subjection of the larger cities. In the face of the resistance of the countryside and of the numerous, not altogether unimportant smaller towns, the Members were unable to exercise the permanent military force upon which their monopoly of power had necessarily to be based (any military mobilization would upset the economic life of the cities). Moreover the mutual rivalry among the three Members prevented them from making a united

(1) The Three Members together paid 39 to $46 \%$ of all taxes in the county during the 14th century: W. Preventr, De beden in het graafschap Vlaanderen onder Filips de Stoute (1384-1404), in Revue belge de Philologie et d'Histoire, XXXVIII, 1960, p. 330-365.

(2) H. Pirenne, Les dénombrements de la population d'Ypres au XV' siècle (1412-1506), in Vierteljahrschrift für Sozial- und Wirtschaftsgeschichte, I, 1903, repr. Histoire économique de l'Occident médiéval, s.1., 1951, p. 467 : the total population of Ypres fluctuated from 10.736 in 1412 to 7.626 in 1491 and 9.563 in 1506 ; in the beginning of the 14th century there were about 28.000 inhabitants: $H$. VAN WERvere, De omvang van de Ieperse lakenproduktie in de veertiende eeuw, Mededelingen Kon. Vlaamse Academie, Letteren, IX, 2, Antwerp, 1947, p. 13 and n. 35 ; Ghent : about 56.000 inhabitants in $1356:$ H. VAN Werveke, Het bevolkingscijfer van de stad Gent in de veertiende eeuw, in Miscellanea Van der Essen, Leuven, 1947, p. 345354 ; Bruges : about 35.000 inhabitants in 1338-40 : J. F. Verbruggen, Het gemeenteleger van Brugge van 1.338 tot 1340 en de Namen van de weerhare Mannen, Kon. Comm. Geschiedenis, in-80 Brussels, 1962, p. 80, with corrections by C. WYFkELs in Tijdschrift voor Geschiedenis, 76,1963, p. 231-233. 
attempt to gain control of power when the weakness of the central authority bade them a chance thereto. That it was not possible for one of them alone to separate itself from the count's authority had indeed been definitely shown by the Ghent war (1379-1385) ( $\left.{ }^{1}\right)$. The gradual growth of rural industries accentuated more sharply the contrast between the cities and the countryside, insofar that during the fifteenth century the economic monopoly of the cities was broken ( ${ }^{2}$ ).

Along with the economical stagnation and the lost chances for self-government, the balance of power moved in the fourteenth century in favour of the sovereign, to the disadvantage of the cities. This was especially so when the Burgundians ascended the throne as these had larger and continuously expanding means at their disposal than merely their Flemish possessions, and were in a position to incite the nobility and the clergy to take a more active part in politics. At that moment, therefore, the theoretical conditions mentioned by Prof. Lyon as necessary for the establishment of a constitution in Flanders, existed.

In this connection it should be pointed out that even prior to this new equilibrium in Flanders a document was drawn up, the context and form of which is absolutely comparable with the constitutions of England, Liège and Brabant. From the first phase of the Ghent war a peace treaty was drawn up dd. December $1,1379\left({ }^{3}\right)$, which has been known for a long time $\left.{ }^{4}\right)$, but which, after a comparison with the constitutions of various countries, may now for the first time

(1) D.M. NraHolas dealt throughly with this problem in Town and countryside: social and economic tensions in fourteenth century Flanders, in Comparative Studies in Society and History, $\mathrm{X}, 1968, \mathrm{p} .458-485$. His view is too abstract however, wherc he considers as unwillingness of the Members to reform themsclves into city-states the juridical symptoms of their incapability of realizing that reform (for ex. why the Members did not take advantage of their position as «chef de sens», or of the properties on the countryside of their inhabitants).

(2) E. CoornaErt, Draperies rurales, draperies urbaines; l'évolution de l'industrie flamande au moyen age et au XVI' siècle, in Revue belge de Philologie et d'Histoire, XXVIII, 1950, p. 60-98.

(3) Espinas-Verlinden-Buntinx, Privileges, vol. I, nr. 10, p. 18-20.

(4) The former authors saw this document in the only connection with the opposition between the Three Members on one hand, and the count with the countryside on the other : Dhondt, Origines, p. 46-47 and Prevenier, Leden en Siaten, p. 47. 
be looked upon as a constitutional text. After negotiations conducted

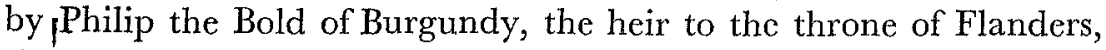
the count proclaims amnesty for the rebels and confirms all existing privileges of the subjects. He furthermore ordains that all his bailiffs and their officials will be discharged; those who so desire may defend themselves in court, which will render judgment whether or not they may continue in office or whether they must leave dcfinitely. In this way there will not be any discrimination, but justice. In particular the Provost of St. Donatian at Bruges, who was no other than the chancellor of Flanders, will be banished from the county and never again be admitted to the Count's Council. To investigate and to punish all future violations of the burgesses privileges in the entire county, a commission will be set up. Its 25 members will be appointed annually by the magistrates of the Three Mcmbers ( 9 by Ghent, 8 each by Bruges and Ypres). Bound by oath these members will be authorized to punish all previous and future transgressions, by applying the current procedure.

5. Item, dat alle baillius ende cnapen, vanghers zijnde ter tijt van nu, verlaten zullen zijn. Ende die ghenieten durven ende willen wet ende vonnesse bi der inquesten ende niet mesdadich bevonden werden zullen moghen staen ghelijc haren gheburen. Ende die mesdadich bevonden werden zullen bliven verlaten ende nemmermeer in officien ghestelt, (updat) denghonen, $d$ (ie over) de inqueste $\mathrm{z}(\mathrm{itten})$ zullen, redelijc dinct ende zij twijsen, omdat niemene zal moghen zegghen, dat $m$ (en bi willc) voortghaen wille, maer bi wet ende vonnessen.

6. Item, (dat) de proofst (van) Sente-Donaes zal buten lande van Vlaendren bliven zonder enich middel ende verlatene van (onsen) rade ende nemmermeer t'onsen rade te (zine).

7. Item, dat (men de) inqueste (doen) zal al Vlaendren duere van allen denghonen, die hem mesdreghen hebben in contrarien den previlegen ende vryheiden van den com(mune; ende die men mesdadich be)vint, dat menne naer verdiente corrigieren zal ; ende dese inqueste ende correxie ghedaen ende bezeten te zine bi denghonen, diere de drie steden. (over ghelieft te he)bbene ende diere over wezen zullen bi onsen bailliu eed derof doende ende niemene derin te spaerne. Ende waert dat in ons ende onsen bailliu ghebrec ware (dat) de wet van den drien steden elke, die zoe ghecoren zal hebben, haren eed staven zal moghen om de inqueste ghehouden te zine, ghelijc dat 't point. verclaert. Ende om ons ende onse goede liede te verwaerne voordan ende elken es gheaccordeert, dat elx jaers eewelike ghedaen zal zijn eene inqueste bi 
vive ende twintich personen, emmer de dartiene ende niet min derover zijnde, ghecoren uten ghemeenen lande van Vlaendren bi der wet van den drien steden ; ende de vorseide vive ende twintich personen elx jaers te vernieuwene bi den wetten van den drien steden, die danne wezen zullen; van welken vive ende twintich personen die van Ghend zullen kiesen de neghene, die van Brugghe de achte ende die van Yppre de achte ; ende ghevielt dat eneghe van den vive ende twintich personen storven, dat de wet, diese ghecoren hadde, andre zullen moghen kiesen in haer stede, alzo vorseit es, om up deghone, die hem voordane mesuseren zullen, correxie te gheschiene, wie zij zijn, naer verdiente, om de goedelieden ghemeenlike te blivene in haer prcvilegen ende vryheden; ende dat alle de proffite, diere of commen, ons toebehoren zullen, behouden den steden haer recht te hebbene derin als verre, als zij ' $t$ sculdich zijn te hebbene naer costumen ende usagen van ouden tiden.

The similarity with the terms of the Peace of Fexhe (also a peace treaty !) and of the Charter of Kortenberg is striking : confirmation of existing privileges, measures against officials who violate them, and the establishment of an investigation commission. The confirmation of the Charter of Kortenberg in 1372 and the proclamation of the Peace of the XXII in 1373 clearly inspired the authors of the Flemish Peace of the XXV. Who could have taken this initiative? It is possible that the three large cities saw a chance herc to fortify their dominating position to the detriment of the count and the countryside (1). It nevertheless seems strange that to attain this they should have created an organ that was nothing else but a fixed form of their assemblies of the Members the strength of which did indeed lie in their suppleness. The more, we noted that the unrivalled power of the Brabant citics made superfluous the Council of Kortenberg since 1383. The same argument secms valuable in Flanders.

We have pointed out before the absence in Flanders of any tradition as to landcharters. Neither had there becn any experience with control commissions so that it is likely that the idea did not emanate exclusively from the Mcmbers but also from the negotiator, the cunning diplomat Philip the Bold who desired to introduce a uniform solution - at least formally -- after the cxample of Brabant and Liège. $\mathrm{Be}$ that as it may the Ghent war struggled on for another six years so that the actual carrying out of the peace treaty was not long

(1) Prevenier, Ibud. 
considered $\left(^{1}\right)$. Its importance lies more in the radiation of the Brabant and Liège constitutions rather than in the application given to it in Flanders, seeing that from the beginning it was considered here as alien. A comparison of the composition of the investigation commissions nevertheless clearly reveals the relation of power:

- Brabant : 4 noblemen and 6 cities : 3 representatives for Louvain and Brussels, 2 for Antwerp (since 1332, before only 1), 1 for s'-Hertogenbosch, Tienen and Zoutleeuw.

- Liège : 4 members of the St. Lambert Chapter, 4 noblemen and 14 representatives of 9 cities: 4 representatives for Liège, 2 for Huy and Dinant, 1 for Tongeren, St.- Truiden, Loon, Hasselt, Fosses and Thuin $\left({ }^{2}\right)$.

- Flanders : 3 cities : Ghent, Bruges, Ypres, represented in practically equal numbers.

$$
\text { *** }
$$

Finally there remains to be examined under what circumstances the Flemish obtained their first constitution in 1477 and what the extent of it was. We have already seen that from the end of the 14th century the objective conditions in Flanders were favourable for setting up a constitution. This does not mean, however, that the necessity for such was felt: in the same way that the aforementioned act of 1436 gave recognition to the intervention of the Members in all matters, they still played an important role in the government of the county. Not until the headstrong duke Charles the Bold had utterly ignored the unwritten laws of the Estates in various fields, did these latter consider it an urgent necessity to have their authority fixed formally. It should be added also that the Flemish were at that time involved in a general wave of revolt and that they therefore were not the only ones to take the initiative. The Flemish privilege

(1) R. Demornck, De Gentse Oorlog (1379-1395). Oorzaken en Karakter, in Handelingen Maatsch. Geschied. en Oudh. Gent, V, 1951, p. 305-318; p. 317-318.

(2) Lejeune, Liege et son pays, p. 367 and 398. In 1343 St.-Truiden and Tongeren held two chairs each instead of Loon and Hasselt, Bouillon instead of Thuin. 
was issued together with the Great Privilege for all the duchess' countries, together with many other country and town privileges $\left(^{1}\right)$.

In these landcharters, wrung from the weak daughter of Charles hardly a month after his death by the excited population, many articles refer to violation of the unwritten laws by the Duke, likewise after the death of Philip the Bold, complaintbooks, "cahiers de doleances", were submitted to his son and successor, John the Fearless, which in the same way resulted in various promises $\left({ }^{2}\right)$. In the Flemish Privilege ( $\left.{ }^{3}\right)$ a whole series of clauses was dedicated to the fight against corruption in the appointment of magistrates and law officers, and during their state of office. Indeed during the reign of Charles the Bold the duke's influence had much increased in the appointment of aldermen : the number of magistrates was overcrowded by creatures whose career were often crowned by a promotion to the duke's service "for service rendered". Charles had carried things so far as to sell municipal functions to favourites, and even to create new posts when it was the custom to entrust this solely to the municipal authorities. These practices still persisted under the reign of the archduke Maximilian of Austria, notwithstanding the Privilege. No change was made in the procedure whereby aldermen from a small exclusive group were appointed by royal commissioners. The articles rather express the pious hope, for an effective action against corruption was not attempted. In Ghent revenue was reclaimed from about a hundred "unlawfully appointed" ex-aldermen in the period 1455-1466 $\left.{ }^{4}\right)$, but this did not touch the root of the problem and was but a slight intervention (the most recent appointments were ignored, the restitutions remained far below the unlawfully collected amounts). The farming of the functions of bailiff (the most important but not expli-

(1) P. Van Ussel, De regering van Maria van Bourgondie in de Nederlanden, Leuven, 1944, Chapters III-V give a good survey.

(2) Prevenier, o.c., p. 149.

(3) Analysis : L. Gilliodts-Van Severen, Inventaire des Chartes, vol. VI, Bruges, 1876, p. 121-130 (Ch. no. 1142) ; P. VAN Duxsc-E. DE Busscher, Inventaire analytique des Chartes et documents appartenant aux archives de la ville de Gand, Ghent, 1867, p. 245-246 (Ch. no. 707). Edition: Verzameling van XXIV originele charters, privilegien en keuren van de provincie van Vlaanderen van de $X I I I^{\circ}$, $X I V^{\mathrm{e}}$ en $X V^{\mathrm{e}}$ eeuw, Ghent, (1787-88), no. 10, p. 61 et sq.

(4) Ghent, Stadsarchief, City count 18 February-15 August 1477, fo $418 \mathrm{r}^{\circ}, 422 \mathrm{r}^{\circ}$. 
citly mentioned !) was not prevented by the Flemish Privilege for, notwithstanding the cancellation by the Members of a farming in 1480, the practice of corruption spread even more extensively than before. In 1495 it was even officially defended $\left({ }^{1}\right)$. Various clauses about the use of the language of the country were more respected. Official Flemish documents were henceforth drawn up in Dutch by the central administration and also a high court of law, such as the Council of Flanders, proccded to issue its accounts in the common language... at least during the periods of open revolt 1483 and 1484 and again in 1488 and 1489, when French again became the official language $\left({ }^{2}\right)$. Wc notice that here too the traditional powers soon regained ground after a strategical retreat.

The heavy and fastly increasing burden of taxation under Charles the Bold may rightly be considered as one of the main causes of the outburst of dissatisfaction after his death. Whereas the figures in the last years of his reign amounted to twice those in the beginning and strongly increased in consequence of the wars on all fronts, specially in 1475, the aids granted in the first years of Maximilian's reign did certainly not remain beneath this exceptionally high level notwithstanding a decrease in the international military operations $\left({ }^{3}\right)$. A few clauses of the Flemish Privilege pertain to taxes : these were only to be granted by common consent of the Members. Indeed Charles had, more than once, played off one of the Members against the other by granting special advantages to one of them; the duke had also used minor towns to turn the scales in his favour. He even tried to make the consent of the Members superfluous by authoritative claims. However, in July 1477 an aid was already agreed to against the wish of Ypres. For the rest, the archduke skilfully sailed around refusals by limiting his requests for aids to well defined circumscriptions, and only now and then to the whole county. Even if some articles of the Privilege were violated, some others could still be circumvented.

(1) J. Van Rompaex, Het grafelijk baljuresambt in Vlaanderen tijdens de Boergondische periode, Brussels, 1967, p. 385 and sq., mainly p. 389-391.

(2) Brussels, Algemeen Rijksarchief, Rekenkamer, nos. 21852-21853 and 21858-21859.

(3) A study on the exact rates is being prepared now. 
Coinage is of primary importance : it has already been mentioned that the Members had closely been involved in the mattcr as of old. In 1468 Gharles the Bold has still respected this custom but in 1474 he totally ignored the Members upon the issue of a new coin decree. As a result the Flemish Privilege contains the clause that neither the rate of exchange nor the alloy could bc modified without the consent of the Three Members. A more striking violation of this cannot be imagined than when Maximilian, from 1485 until 1492 following a procedure which had fallen into abeyance for more than a century, enforced a series of devaluations of the alloys, thus procuring for himself a seigniorage of $16 \%$ when aids were refused him by his subjects ${ }^{(1)}$. Finally the Flemish Privilegc claims the consent of the Three Members for any levying of tolls on merchandise. Charles the Bold had also ignored them in this respect, specially in connection with the duties on alum. In 1488 this clause was again formulated because hardly any satisfaction was obtained by the Members on this point ( $\left.{ }^{2}\right)$. The confirmation of the rights of the Ghurch is also clearly inspired by the abuses of Charles the Bold: the re-introduction of the tax on clerical properties and the taking part in the nomination of dignitarics.

The most important articles of the Great Privilege, also of 11 th February 1477, are the liberty of the Estates General to assemble, and the consultation of this body in case of a declaration of war $\left({ }^{3}\right)$. It is known that since that time the Estates Gcneral did not once assemble spontaneously (in the 15th century). Furthermore the partition of the domains of power between monarch and Estates was not explicitly defined, and no procedure fixed in case of an eventual con-

(1) P. Spufrord, Coinage, taxation and Estates general of the Burgundian Netherlands, in Anciens Pays et Assemblées d' Etats, XL, 1966, p. 61-88, mainly p. 81-84; H. ENNo VAN GeLder, De rekeningen van de Vlaamse munt onder Philips de Schone, in Revue belge de Numismatique, CVII, 1961, p. 157-169 and ID., De muntpolitiek van Philips de Schone 1482-1496, in Faarboek voor Munt- en Penningkunde, 38, 1951, p. 42-54.

(2) The policy of Charles the Bold towards the Flemish Estates will form a part of a study that we are preparing now.

(3) Analysis : Grlurodts-Van Severen, Inventaire, vol. VI, p, 132-134 (Ch. nos. 11451146) ; Van DuYse-De Busscher, Inventaire, no. 706, Diegerick, Inventaire, vol. IV, no. 1062 ; edition : Verzameling van XXIV charters, p. 53 and sq. 
fict. The riots in the following years further prevented the carrying out of these clauses ( ${ }^{1}$ ). Freedom of assembly for the Estates General was once more formally confirmed by the peace treaty signed between Maximilian and the Flemish in May $1488\left({ }^{2}\right)$. Even a fixed annual date and meeting place in turns was stipulated. However, not once in the succeeding years did the Estates General assemble on this first of October! Their authority was clearly defined this time : discussion of the violations of the privileges (cf. Council of Kortenberg and Council of the XXII). In face, however, of the 'revious de facto authority this meant a considerable restriction because before then, the most various subjects had been treated (aids, coinage, commerce, etc.). The abolition of the Parliament of Mechlin and the restriction in the authority of the new High Council were other important clauses in the Great Privilege $\left({ }^{3}\right)$. These articles were constantly infringed, often to the letter, but mostly in spirit for matters of evocation $\left({ }^{4}\right)$, or the use of languages $\left({ }^{5}\right)$, in spite of the numerous protestations by the Three Members mainly in 1480 and 1490 .

$$
* *
$$

The preceding study permits an answer to our initial inquiry about the extent of the constitutions in Brabant and Liège and the lack thereof in Flanders. In January 1477 the influence of the Flemish Estates had reached the lowest point: Charles the Bold had deprived them in part of their traditional powers (intervention in the changing of money value, granting of aids and tolls) and had seriously

(1) H. Pirenne, Le rôle constitutionnel des États-Généraux des Pays-Bas en 1477 et en 1488, in Mélanges P. Fredericq, Brussels, 1904, p. 267-271.

(2) Verzameling van $X X I V$ charters, no. 18.

(3) J. Stengers, Compositzon, procédure et activité Judiciaire du Grand conseil de Marie de Bourgogne pendant les trois premières années de son existence (février 1477-février 1480), in Bulletin Comm. roy. Histoire, GIX, 1945, p. 1-51; p. 1-2.

(4) Stengers, o.c., p. 31-33.

(5) Srengers, o.c., p. 30-31. In 1481, a flemish request to the High Counsel was drawn up in both languages, French and Dutch : Brussels, Algemeen Rijksarchief, Rekenkamer, $44304, f^{\circ} 54 \mathrm{r}^{\circ}$ : an mijnen gheduchten heere ende an mijnen heeren van zinen hoghen Rade, wien zij te kennen gaven bij supplicacien in Walsche ende in Vlaemsche ende ooc bij monde de zaken vorscreven. 
violated the rights of the cities (corruption of magistrates and officials, appointment of functionaries). In the turbulent atmosphere of January 1477 and driven by a general tendency the Three Members thought they might regain their former position by having their authority written down on paper. Could such texts, extorted by force of circumstances from an inexperienced princess, abandoned by her counsellors, offer any guaranty? Their worth was probably as small as the concessions made on parchment by Maximilian during his imprisonment in 1488. For the Estates of Flanders who for ages had played a role of vital importance merely on a basis of unwritten common law, such a privilege could be but an expression of weakness, a fancied support when they felt the foundation of their power giving way. The formulation of their authority could but limit its extent. Even worse : the enormous sheets of parchment with Great Seals were ignored by the sovercign as soon as the rebellious feeling had died down and his own position became stronger. $\mathrm{He}$ could afford such a procedure because a mass mobilisation of the minds occurs but very exceptionally. From this point of view the Flemish events confirm those of the other regions. The essential fact is that all constitutional texts were drawn up at a time when the central power was very weak. Such exceptional circumstances, however, are transitory: revolutionary coalitions are of short duration and heirs to the throne are bound to attain their majority one time or another. At such moments the balance of power may again be different from what it was at the time the constitution was formed, usually anew in favour of the sovereign who has the advantage of coping with a heavy and divided mass of opponents. A constitution therefore does reflect a "balance of power", but only for a short time. A study of subsequent events clearly shows that it is but a labile balance, a snapshot as it were of the highest pitch of the tide. Finally the reflux should also be measured to see the importance of the benefits gained.

In the end the comparison between Brabant and Flanders has made it clear that constitutions give no explanation and but seldom motivate the influence of the subjects in government matters. To this end their existence is indeed not imperative and they give no real guaranty. The reason why we have emphasized the non-observance of the constitutions is that up to now the studies of their extent have 
strongly deformed the picture. We do not, however, wish to minimize their significance, at the most, only to relativate it. A constitutional text was in any case a gain for the subjects, even involving sometimes a notable effect, however small it might be (ex. Brabant enquêtes and Liège Council of XXII). We specially attach much importance to constitutional texts because they furnish us a precise picture of the claims formulated at a certain moment by the representatives of the people. This information, which sometimes has the aspect of real dossiers of complaints, is very valuable in gathering knowledge of facts and of the forces at work, but also of the level of the political maturity of the people. As an historical phenomenon the constitutions have had also the great significance of at least formulating values, claims and rights, so that in subsequent years they were a source of inspiration for further actions - be this largely fictive and idealized $\left({ }^{1}\right)$.

\section{R. Van Uytven - W. Blockmans.}

(1) LyoN, Fact and fiction, gives an interesting survey of the interpretations during the modern and contemporaneous periods of the « Blijde Inkomst » of 1356. 